\title{
SINTASAN Cronobacter sakazakii pGFPuv SELAMA PENYIMPANAN JAGUNG PIPILAN BERKADAR AIR AWAL BERBEDA DI BERBAGAI RH
}

\author{
[Survival of Cronobacter sakazakii pGFPuv on Corn Kernels \\ with Different Initial Moisture Content during Storage at Various $\mathrm{RH}]$
}

\author{
Karina Nola Sinamo"), Suliantari ${ }^{2,3)}$, dan Ratih Dewanti-Hariyadi ${ }^{2,3) \star}$ \\ 1) Program Studi IImu Pangan, Sekolah Pasca Sarjana, Institut Pertanian Bogor, Bogor \\ 2) Southeast Asian Food and Agricultural Science and Tecnology Center, Institut Pertanian Bogor, Bogor \\ 3) Departemen IImu dan Teknologi Pangan, Fakultas Teknologi Pertanian, Institut Pertanian Bogor, Bogor
}

Diterima 11 Agustus 2016 / Disetujui 30 November 2016

\begin{abstract}
Cronobacter sakazakii is an opportunistic foodborne pathogen reported to cause necrotizing enterocolitis, bacteremia, and meningitis in certain groups of infant. C. sakazakii has been reported to survive at low $a_{w}$ or dryness. Presence of wild-type $C$. sakazakii in dry product is difficult to be distinguished from naturally occuring $C$. sakazakii. A pGFPuv mutant of $C$. sakazakii has been reported to have similar growth pattern, thus has the potential to be used in further investigation. The study aimed to evaluate the effect of initial moisture content and relative humidity $(R H)$ on the survival rate of $C$. sakazakii pGFPuv in corn kernels during storage at room temperature. The study consists of drying corn kernels to achieve moisture contents of 12 and $16 \%$ (w.b), inoculation of C. sakazakii pGFPuv, and storage at RH 50, 70 and $90 \%$ for 12 weeks. Every two week, corn kernels were sampled and the moisture content was measured using oven method, water activity was measured with $a_{w}$ meter, and total C. sakazakii pGFPuv was enumerated by spread plate method. Meanwhile, total bacteria, mold and yeast were enumerated by pour plate method. Corn kernels achieved equilibrium moisture content and $a_{w}$ after two weeks of storage. The number of C. sakazakii decreased rapidly during storage at $\mathrm{RH} 70$ and $90 \%$, however they could survived at RH 50\% for 12 weeks, especially when the initial moisture content was $16 \%$. The total bacteria decreased by 3.5-3.9 Log CFU/g during storage at three RHs, but mold and yeast increased rapidly at $\mathrm{RH}$ $90 \%$.
\end{abstract}

Keywords: corn, Cronobacter sakazakii, pGFPuv, moisture content, RH, storage

\begin{abstract}
ABSTRAK
Cronobacter sakazakii adalah bakteri patogen bawaan pangan oportunistik yang dapat menyebabkan necrotizing enterocolitis, bacteremia, dan meningitis pada kelompok bayi tertentu. $C$. sakazakii telah dilaporkan dapat bertahan pada lingkungan dengan $\mathrm{a}_{w}$ rendah atau kodisi kering. Penggunaan inokulan C. sakazakii wild-type pada produk kering sulit dibedakan dengan $C$. sakazakii yang secara alami sudah ada pada produk tersebut. Mutan C. sakazakii pGFPuv telah dilaporkan memiliki pola pertumbuhan serupa dengan isolat wild-typenya, sehingga dapat digunakan untuk tujuan penelitian ini. Penelitian ini bertujuan untuk mengetahui pengaruh kadar air awal dan kelembaban relatif $(\mathrm{RH})$ terhadap sintasan $C$. sakazakii pGFPuv dalam jagung pipilan selama penyimpanan pada suhu ruang. Penelitian ini terdiri dari pengeringan jagung pipilan untuk mencapai kadar air awal 12 dan $16 \%$ (bb), inokulasi $C$. sakazakii pGFPuv, dan penyimpanan pada $\mathrm{RH}$ 50, 70 dan 90\% selama 12 minggu. Setiap dua minggu, jagung pipilan diukur kadar airnya dengan metode oven, aktivitas airnya dengan $a_{w}$ meter, dan dihitung jumlah C. sakazakii pGFPuv dengan metode sebar, total bakteri dan jumlah kapang dan khamir dengan metode tuang. Jagung pipilan mencapai kadar air dan $a_{w}$ kesetimbangan setelah 2 minggu penyimpanan. Jumlah C. sakazakii pGFPuv menurun dengan cepat selama penyimpanan pada $\mathrm{RH} 70$ dan $90 \%$, tetapi C. sakazakii pGFPuv dapat bertahan hidup pada $\mathrm{RH} 50 \%$ selama 12 minggu penyimpanan, terutama pada kadar air awal 16\%. Total bakteri menurun sebesar 3,5-3,9 Log CFU/g pada ketiga RH penyimpanan, sedangkan jumlah kapang dan khamir meningkat pada $\mathrm{RH} 90 \%$.
\end{abstract}

Kata kunci: Cronobacter sakazakii pGPuv, jagung pipilan, kadar air, penyimpanan, $\mathrm{RH}$

Naskah telah dipresentasikan dalam International Conference 2016, Food Innovations: AEC Challenges, 21-22 September 2016, Jakarta. *Penulis Korespondensi: E-mail: rdewantih@yahoo.com 


\section{PENDAHULUAN}

Cronobacter sakazakii adalah bakteri patogen bawaan pangan oportunistik yang dapat menyebabkan gejala infeksi seperti radang usus (necrotizing enterocolitis), keracunan darah (bacteremia), dan radang selaput otak (meningitis) pada kelompok bayi tertentu dengan tingkat kematian $50-80 \%$ (Healy et al., 2010). Menurut FAO-WHO (2008) sejak tahun 1958 sampai juli 2008 di dunia telah terjadi 120 kasus infeksi $C$. sakazakii pada bayi dan anak-anak sampai usia 3 tahun. Pada tahun 2010 dilaporkan adanya dugaan transmisi $C$. sakazakii dari susu formula ke bayi yang menyebabkan dua bayi sakit di Mexico (Jackson et al., 2015). Sumber kontaminasi $C$. sakazakii dapat berasal dari lingkungan dan makanan (Iversen dan Forsythe, 2003). C. sakazakii telah diisolasi dari beberapa makanan seperti susu formula bayi, makanan bayi kering, produk keju dan ingredien makanan kering seperti bumbu dan rempah-rempah (Estuningsih et al., 2006; Friedamann, 2007). Akan tetapi, hanya susu formula yang dihubungkan dengan infeksi C. sakazakii (Bowen dan Braden, 2006).

C. sakazakii dilaporkan lebih resisten terhadap kekeringan dibandingkan bakteri E. coli, Salmonella, dan Enterobacteriaceae lainya dan dapat bertahan dalam kondisi kering lebih dari 2 tahun (Breeuwer et al., 2003; Osaili dan Forsythe, 2009). C. sakazakii sudah dilaporkan bertahan dalam susu skim bubuk selama penyimpanan 3 bulan pada $\mathrm{RH} 50,70$ dan 90\% (Dewanti-Hariyadi et al., 2012). Bakteri patogen ini bertahan lebih baik pada akivitas air $\left(\mathrm{a}_{\mathrm{w}}\right)$ rendah $(0,25-0,30)$ daripada $a_{w}$ tinggi $(0,69-0,82)$ selama penyimpanan 12 bulan (Beuchat et al., 2009). Penurunan jumlah $C$. sakazakii pada susu formula lebih besar pada $a_{w} 0,43-0,50$ daripada $a_{w} 0,25-0,30$ selama penyimpanan 12 bulan (Gurtler dan Beuchat, 2007).

Kemampuan C. sakazakii bertahan pada produk pangan kering selama penyimpanan berpotensi menjadikan produk pangan kering tersebut sebagai sumber bakteri patogen $C$. sakazakii. Untuk meneliti sintasan $C$. sakazakii pada produk pangan kering, penggunaaan galur wild-type memiliki keterbatasan karena tidak dapat dibedakan dari $C$. sakazakii yang mungkin terdapat secara alami pada produk pangan tersebut. Untuk itu, penelitian ini memanfaatkan mutan C. sakazakii hasil transformasi dengan plasmid yang mengandung gen penyandi green fluoresencent protein (pGFP) yang dapat berpendar hijau (Nurjanah et al., 2014). Jagung dipilih karena secara luas digunakan sebagai bahan baku untuk produk pangan kering, baik dalam bentuk pati maupun tepung jagung. Selain itu, beberapa penelitian menunjukkan $C$. sakazakii telah diisolasi dari jagung atau produk turunan jagung (Restaino et al., 2006; Gitapratiwi et al., 2012). Kadar air awal jagung dan kelembaban udara ruang penyimpanan $(\mathrm{RH})$ diduga dapat mempengaruhi sintasan C. sakazakii selama proses penyimpanan. Untuk itu, pada penelitian ini penyimpanan jagung dilakukan dengan kadar air awal jagung (12 dan 16\% bb) dan tingkat kelembaban udara ruang penyimpanan yang berbeda (RH 50, 70, dan 90\%).

Tujuan dari penelitian ini adalah untuk mengevaluasi sintasan $C$. sakazakii selama penyimpanan jagung pipilan dengan kadar air awal bahan dan $\mathrm{RH}$ (relative humidity) yang berbeda dengan menggunakan mutan C. sakazakii pGFPuv. Hasil penelitian ini diharapkan dapat dimanfaatkan sebagai dasar pertimbangan dalam menyimpan jagung pipilan pada kondisi kadar air awal bahan dan $\mathrm{RH}$ ruang penyimpanan yang tepat sehingga keamanan pangan terjaga.

\section{BAHAN DAN METODE}

\section{Bahan}

Bahan-bahan yang digunakan dalam penelitian ini antara lain jagung varietas Pioneer P27 Gajah (Kebun Percobaan IPB Cikabayan, Indonesia) dan isolat Cronobacter sakazakii pGFPuv E2 yang sudah ditransformasi dengan plasmid pGFPuv (SEAFAST Center, Indonesia).

\section{Pembuatan jagung pipilan}

Jagung varietas Pioneer P27 Gajah dengan umur panen 98 hari dipipil secara manual dan dikeringkan dengan cabinet dryer (H.ORTH GmbH, West Germany) pada suhu $50^{\circ} \mathrm{C}$ hingga diperoleh jagung pipilan dengan kadar air yang diinginkan yaitu 12 dan $16 \%$ bb.

\section{Konfirmasi isolat Cronobacter sakazakii pGFPuv}

Konfirmasi isolat $C$. sakazakii pGFPuv mengacu pada penelitian Nurjanah et al. (2013). Stok beku isolat mutan $C$. sakazakii pGFPuv diinkubasi dalam media Brain Heart Infusion (BHI) (Oxoid Ltd, UK) yang disuplementasi $100 \mu \mathrm{g} / \mathrm{mL}$ ampisilin (PT. Erita Farma, Indonesia) pada suhu $37^{\circ} \mathrm{C}$ selama 24 jam. C. sakazakii pGFPuv dikonfirmasi dengan menumbuhkannya pada media TSAA yaitu media Tryptic Soy Agar (TSA) (Oxoid Ltd, UK) yang disuplementasi $100 \mu \mathrm{g} / \mathrm{mL}$ ampisilin dengan cara menggoreskan satu loop ke permukaan media tersebut. Setelah itu, kultur diinkubasi menggunakan inkubator (Heraeus, Germany) pada suhu $37^{\circ} \mathrm{C}$ selama 24 jam dan diamati di bawah sinar lampu UV (Desaga, Heidelberg, Germany) dengan panjang gelombang $366 \mathrm{~nm}$. Koloni C. sakazakii pGFPuv akan tampak berfluorosen (berpendar hijau). 


\section{Persiapan Cronobacter sakazakii pGFPuv se- bagai Inokulum}

Pembuatan inokulum C. sakazakii pGFPuv mengacu pada penelitian Nurjanah et al. (2013). Koloni berfluoresen yang tumbuh pada media TSAA disuspensikan dengan larutan pengencer Buffered Peptone Water (BPW) (Oxoid Ltd, UK) dan disentrifugasi menggunakan sentrifus (HERMLE Z383K, Germany) dengan kecepatan 3500 rpm $(2.600 \times$ g) selama 10 menit pada suhu $4^{\circ} \mathrm{C}$. Setelah supernatan dibuang, pelet dicuci dengan $10 \mathrm{~mL}$ BPW dan disentrifugasi kembali. Pelet sel diresuspensi dalam BPW, distandarisasi jumlah selnya dengan mengukur Optical Density (OD) pada $\lambda=590 \mathrm{~nm}$ menggunakan spektrofotometer UV-VIS (Shimadzu UV2450, Japan). Pengenceran dilakukan sampai mencapai nilai OD 0,4 yang setara dengan jumlah koloni $10^{8} \mathrm{CFU} / \mathrm{mL}$, dan selanjutnya suspensi mutan ini digunakan sebagai inokulum.

\section{Inokulasi dan penyimpanan jagung}

Sejumlah C. sakazakii pGFPuv diinokulasikan ke jagung pipilan dalam kantong plastik steril kemudian diaduk rata sehingga jumlah awal C. sakazakii pGFPuv pada jagung pipilan adalah $10^{6} \mathrm{CFU} / \mathrm{g}$. Kemudian, sampel disimpan di dalam botol kaca yang berisi larutan garam teknis $\mathrm{K}_{2} \mathrm{CO}_{3}$ $(\mathrm{RH} \pm 50 \%), \mathrm{NaNO}_{3}(\mathrm{RH} \pm 70 \%)$ dan $\mathrm{BaCl}_{2}(\mathrm{RH}$ $\pm 90 \%$ ) (Shen Zhen Yang Feng Industrial Co., Ltd., China) jenuh pada suhu ruang $\left(27-30^{\circ} \mathrm{C}\right)$ selama 12 minggu (Greenspan, 1977). Percobaan diulang 2 kali untuk setiap perlakuan $\mathrm{RH}$ penyimpanan.

\section{Analisis kadar air dan aktivitas air $\left(a_{w}\right)$ selama penyimpanan jagung pipilan}

Analisis kadar air dan $a_{w}$ dilakukan pada kelompok kontrol setiap dua minggu selama 12 minggu penyimpanan. Kadar air jagung pipilan diukur menggunakan oven kadar air (Memmert, Western Germany) pada suhu $105^{\circ} \mathrm{C}$ selama minimal 6 jam (Nielsen, 2010). Pengukuran $a_{w}$ dilakukan menggunakan alat $a_{w}$ meter (Rotronic, USA) yang telah dikalibrasi (Passot et al., 2012). Analisis jumlah C. sakazakii pGFPuv selama
penyimpanan jagung pipilan
Sebanyak $10 \mathrm{~g}$ sampel dilarutkan ke dalam 90 $\mathrm{mL}$ BPW, dihomogenkan dengan pengocokan manual, dan dilakukan seri pengenceran untuk dipupukan dengan metode sebar ke dalam media TSAA ((TSA) + $100 \mu \mathrm{g} / \mathrm{mL}$ ampisilin). Setelah itu, diinkubasi menggunakan inkubator pada suhu $37^{\circ} \mathrm{C}$ selama \pm 24 jam, kemudian koloni dihitung di bawah sinar lampu UV dengan panjang gelombang 366 $\mathrm{nm}$, sesuai Standard Plate Count (BAM, 2001). Kurva jumlah $C$. sakazakii selama penyimpanan dibuat dengan memplot jumlah koloni $C$. sakazakii (Log CFU/g) pada sumbu $Y$ dan interval waktu (minggu) penyimpanan pada sumbu $X$.

\section{Kurva sintasan $C$. sakazakii selama penyimpa- nan jagung}

Kurva ketahanan hidup isolat $C$. sakazakii pGFPuv dibuat dengan memplotkan logaritma jumlah koloni yang bertahan hidup pada waktu tertentu (Nt) dibagi dengan jumlah koloni awal (No) pada sumbu $Y$ dan interval waktu (minggu) penyimpanan pada sumbu $X$. Laju penurunan jumlah (Log/minggu) selama penyimpanan ditunjukkan oleh besarnya slope dari persamaan linier (Nurjanah et al., 2013).

\section{Analisis statistik}

Perlakuan dilakukan sebanyak dua kali ulangan. Data jumlah C. sakazakii pGFPuv yang bertahan selama penyimpanan diuji normalitasnya dengan metode Saphiro Wilk. Pengaruh kadar air awal terhadap jumlah $C$. sakazakii pGFPuv selama penyimpanan dianalisis menggunakan uji $t$ berpasangan jika data tersebar normal atau menggunakan uji Mann-Whitney jika data tidak tersebar secara normal. Pengaruh $\mathrm{RH}$ ruang penyimpanan terhadap jumlah C. sakazakii pGFPuv selama penyimpanan dianalisis menggunakan One Way Anova dengan uji lanjut Duncan jika data tersebar normal atau uji Friedman dengan uji lanjut Wilcoxon jika data tidak tersebar secara normal.

\section{Analisis total bakteri dan jumlah kapang dan} khamir selama penyimpanan jagung pipilan

Analisis total bakteri dan jumlah kapang dan khamir pada jagung pipilan dilakukan setiap dua minggu selama 12 minggu penyimpanan. Sebanyak $10 \mathrm{~g}$ sampel dilarutkan ke dalam $90 \mathrm{~mL}$ BPW, dihomogenkan dengan pengocokan manual, dan dilakukan seri pengenceran. Total bakteri dianalisis menggunakan metode tuang dalam media Plate Count Agar (PCA) (Oxoid Ltd., UK) dan diinkubasi menggunakan inkubator pada suhu $35^{\circ} \mathrm{C}$ selama \pm 48 jam (BAM, 2001). Jumlah kapang dan khamir dianalisis menggunakan metode tuang dalam media media Potato Dextrose Agar (PDA) (Oxoid Ltd, UK) ditambah asam tartarat 10\% (Merck, USA) dan diinkubasi menggunakan inkubator (Fisher Scientific, USA) pada suhu $25^{\circ} \mathrm{C}$ selama 3-5 hari, mengacu pada penelitian Aguayo et al. (2006).

\section{HASIL DAN PEMBAHASAN}

\section{Perubahan kadar air dan aktivitas air $\left(a_{w}\right)$ jagung pipilan selama penyimpanan}

Kadar air dan $a_{w}$ jagung pipilan mencapai kesetimbangan setelah penyimpanan 2 minggu pada $\mathrm{RH}$ penyimpanan 50,70 , dan $90 \%$ (Gambar 1 dan 2). 

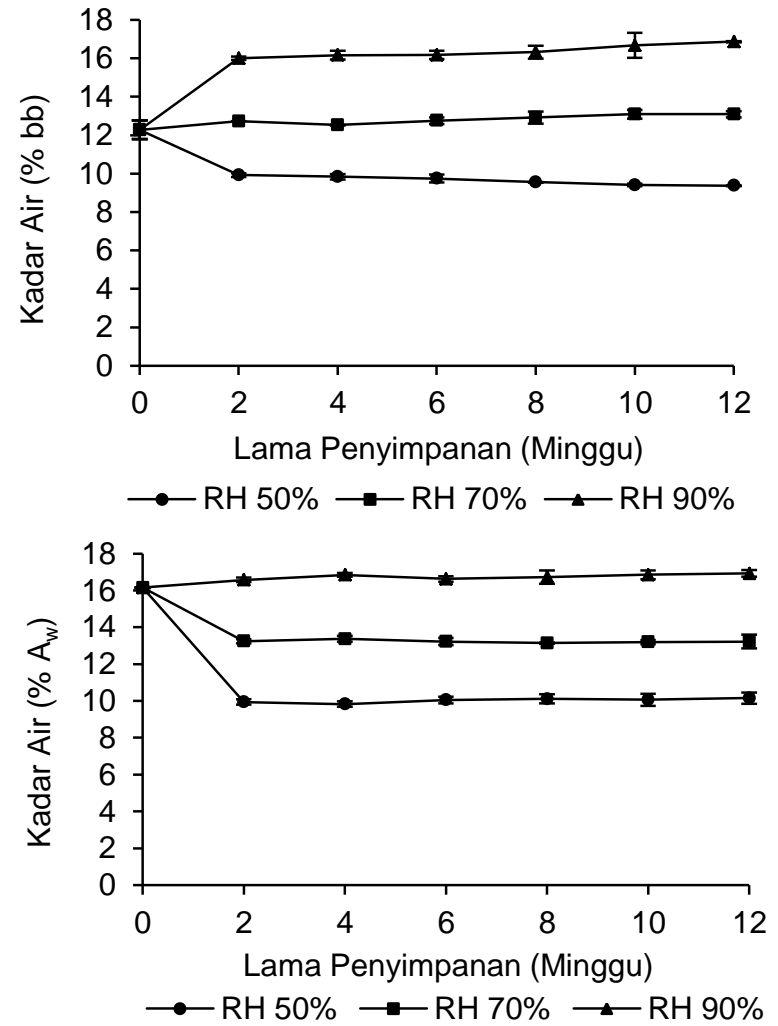

Gambar 1. Perubahan kadar air jagung pipilan dengan kadar air awal $12 \%$ (A) dan $16 \%(B)$

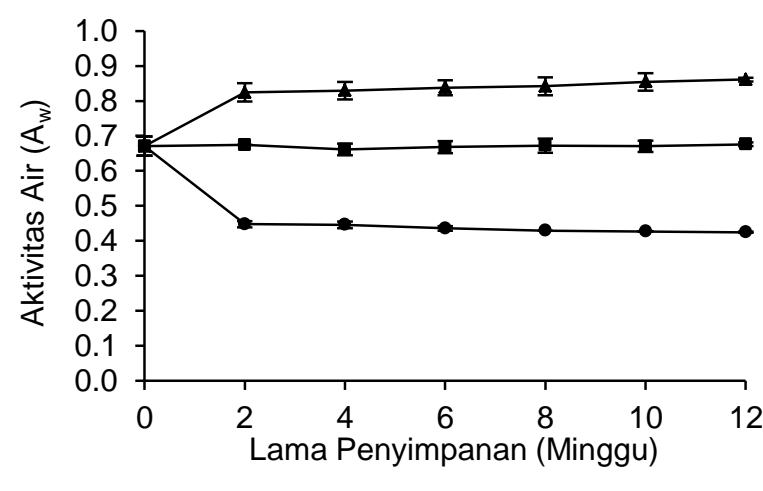

A

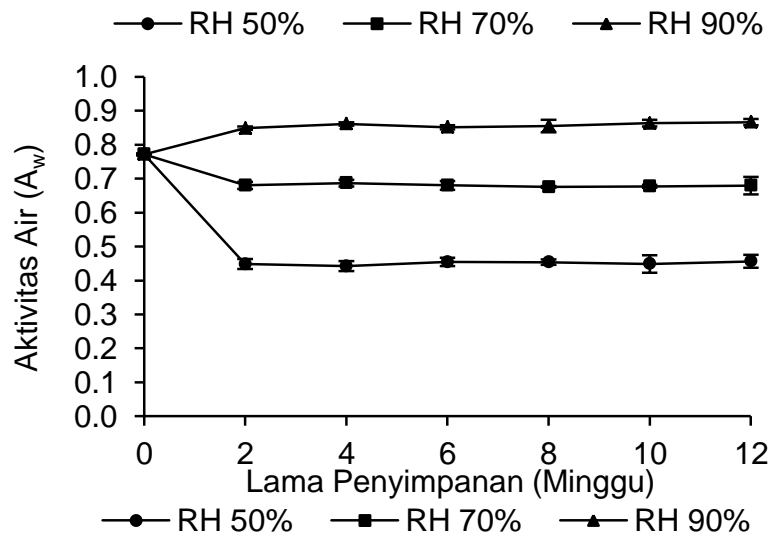

Gambar 2. Perubahan aktivitas air jagung pipilan dengan kadar air awal $12 \%$ (A) dan $16 \%$ (B)

A 
pipilan berkadar air awal 12 dan $16 \%$ di $\mathrm{RH} 50 \%$ berturut-turut sebesar $0,7 \pm 0,92$ dan 2,5 $\pm 0,11$ Log CFU/g sedangkan pada $\mathrm{RH} 70$ dan $90 \%$ sudah tidak ada bakteri $C$. sakazakii pGFPuv yang bertahan. Penurunan $C$. sakazakii pGFPuv pada jagung pipilan berkadar air awal 12 dan 16\% yang disimpan pada $\mathrm{RH} 50 \%$ selama 12 minggu berturut-turut sebesar 5,4 dan 3,8 Log CFU/g. Jumlah C. sakazakii pGFPuv pada jagung pipilan setelah penyimpanan tersebut dipengaruhi oleh $\mathrm{RH}$ penyimpanan $(P<0,05)$. Laporan serupa oleh Dewanti-Hariyadi et al. (2012) juga menunjukkan penurunan $C$. sakazaki pada susu skim selama 12 minggu penyimpanan dipengaruhi oleh $\mathrm{RH}$ penyimpanan, dimana penurunan terbesar terjadi pada $\mathrm{RH} 90 \%$ dibandingkan $\mathrm{RH}$ 50 dan $70 \%$.
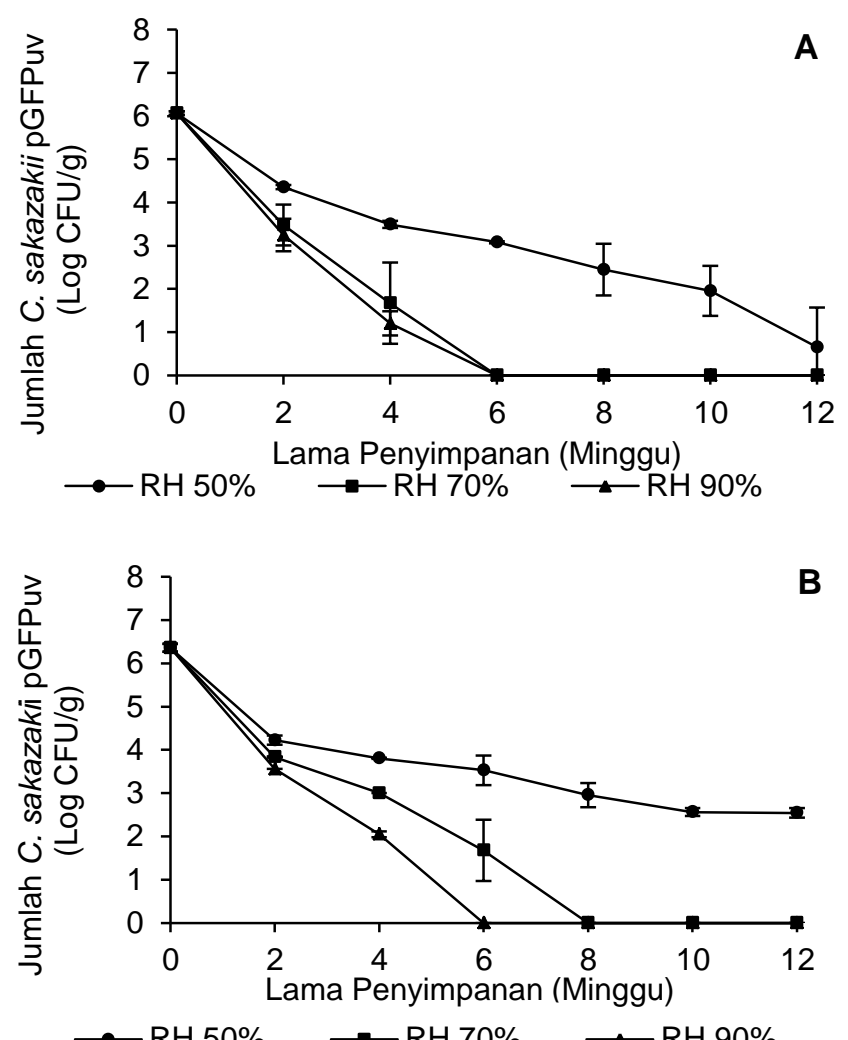

Gambar 3. Perubahan jumlah C. sakazakii pGFP. uv pada jagung pipilan dengan kadar air awal 12\% (A) dan 16\% (B)

Penurunan jumlah $C$. sakazakii pGFPuv yang lambat pada $\mathrm{RH} 50 \%$ juga berkaitan dengan penurunan $a_{w}$-nya selama penyimpanan. Menurut Gurtler dan Beuchat (2007) kelangsungan hidup C. sakazakii meningkat ketika $a_{w}$ sangat rendah. Aktivitas air jagung pipilan yang disimpan pada $\mathrm{RH}$ $50 \%$ lebih rendah daripada $\mathrm{RH} 70 \%$ dan $\mathrm{RH} 90 \%$. $\mathrm{a}_{\mathrm{w}}$ jagung pipilan berkadar air awal 12 dan $16 \%$ di $\mathrm{RH} \mathrm{50 \%}$ berturut-turut sebesar $0,45 \pm 0,01$ dan 0,45 $\pm 0,01$ sedangkan di $\mathrm{RH} 70 \%$ sebesar $0,67 \pm 0,03$ dan $0,68 \pm 0,01$, dan di $\mathrm{RH} 90 \%$ sebesar $0,82 \pm 0,03$ dan
0,85 $\pm 0,00$. Penelitian Beuchat et al. (2009) menunjukkan $C$. sakazakii bertahan lebih baik pada formula dan sereal bayi dengan $a_{w} 0,25-0,30$ daripada $a_{w} 0,69-0,82$ selama penyimpanan 12 bulan. Lin dan Beuchat (2007) menyatakan dengan meningkatnya $\mathrm{a}_{\mathrm{w}}$ dapat mempercepat laju kematian $C$. sakazakii. Selain itu, meningkatnya jumlah kapang dan khamir pada jagung pipilan yang disimpan di $\mathrm{RH} 90 \%$ juga dapat menyebabkan penurunan jumlah $C$. sakazakii pGFPuv yang sangat cepat dibandingkan pada jagung pipilan yang disimpan di $\mathrm{RH} 50 \%$.

Sintasan C. sakazakii pGFPuv pada jagung pipilan dapat diketahui dengan membandingkan laju penurunan jumlah koloni yang bertahan hidup pada waktu tertentu (Nt) dengan jumlah koloni awal (No). Laju penurunan jumlah $C$. sakazakii pGFPuv per minggu ditunjukkan oleh besarnya slope yang diperoleh dari persamaan linier kurva sintasan. Laju penurunan jumlah isolat $C$. sakazakii pGFPuv pada jagung pipilan berkadar air awal 12 dan 16\% yang disimpan di $\mathrm{RH} 50 \%$ lebih lama dibandingkan pada $\mathrm{RH} 70$ dan 90\% (Gambar 4). Hal ini ditunjukkan dengan nilai slope dari persamaan linier $\mathrm{RH} 50 \%$ lebih kecil dibandingkan $\mathrm{RH} 70$ dan 90\%. Pada jagung pipilan berkadar air awal 12 dan 16\%, laju penurunan C. sakazakii pGFPuv pada $\mathrm{RH} 50 \%$ berturut-turut sebesar 0,789 dan 0,557 siklus Log/ minggu, sedangkan pada $\mathrm{RH} 70 \%$ berturut-turut sebesar 2,001 dan 1,487 siklus Log/minggu, dan pada $\mathrm{RH} 90 \%$ berturut-turut sebesar 2,024 dan 2,058 siklus Log/minggu.

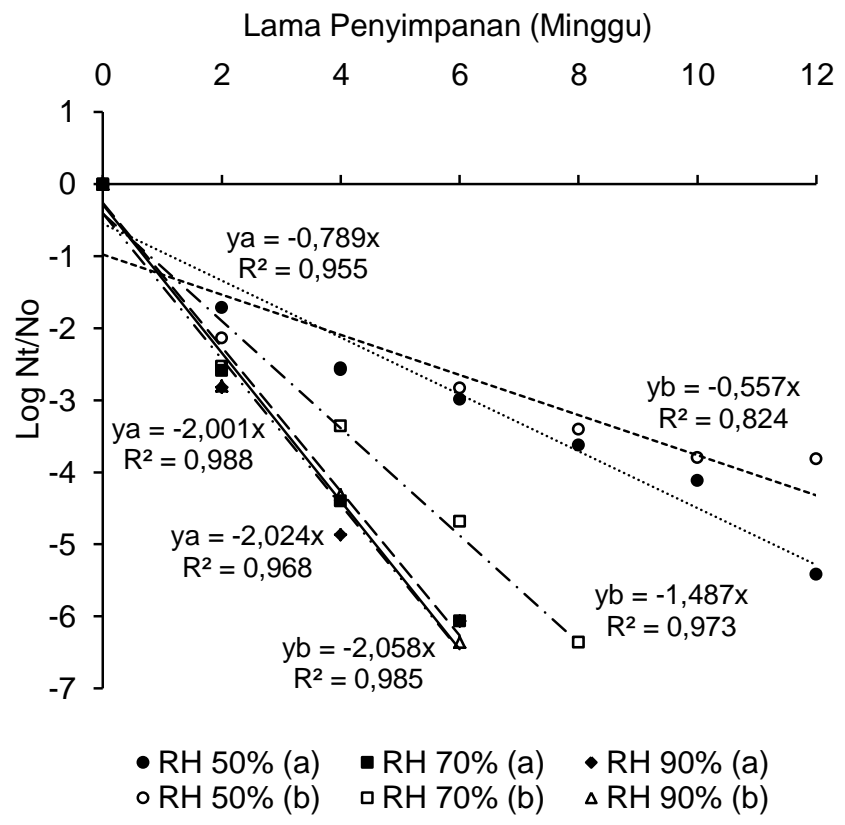

Gambar 4. Sintasan C. sakazakii pGFPuv mutan pada jagung pipilan berkadar air awal $12 \%$ (a) dan $16 \%$ (b) selama penyimpanan pada $\mathrm{RH} 50,70$, dan $90 \%$ 
Pada $\mathrm{RH} 50 \%$, laju penurunan jumlah C. sakazakii pGFPuv di jagung pipilan berkadar air awal $16 \%$ lebih lambat dibandingkan dengan jagung pipilan berkadar air awal $12 \%$. Hal ini ditunjukkan dengan nilai slope dari persamaan garis linier jagung pipilan berkadar air awal $16 \%$ yang lebih kecil dibandingkan dengan jagung pipilan berkadar air awal $12 \%$. Pada $\mathrm{RH} 50 \%$, laju penurunan jumlah C. sakazakii pGFPuv di jagung pipilan berkadar air awal 12 dan 16\% berturut-turut sebesar 0,789 dan 0,557 siklus Log/minggu. Akan tetapi, berdasarkan uji non parametrik independent samples, kadar air awal jagung pipilan berpengaruh tidak nyata $(P>0,05)$ terhadap jumlah $C$. sakazakii pGFpuv yang bertahan hidup di $\mathrm{RH} 50 \%$ setelah penyimpanan. Hal ini disebabkan karena kedua taraf kadar air awal jagung pipilan tersebut pada $\mathrm{RH} 50 \%$ mengalami kadar air kesetimbangan setelah minggu kedua dan memiliki kadar air yang serupa selama penyimpanan. Kadar air jagung pipilan berkadar air awal 12 dan $16 \%$ berturut-turut memilki kadar air selama penyimpanan $9,4-9,9 \%$ dan $9,8-10,1 \%$.

Penelitian Breeuwer et al. (2003) menunjukkan sintasan $C$. sakazakii pada kondisi kering disebabkan oleh kemampuannya mengakumulasi trehalosa, yang berperan dalam menstabilkan membran fosfolipid dan proteinnya. Trehalosa akan berikatan (ikatan hidrogen) secara langsung dengan gugus polar dari fosfolipid sehingga dapat menstabilkan ikatan yang sebelumnya ditempati air (Patist dan Zoerb, 2005). Trehalosa dapat meningkatkan tegangan permukaan dengan cairan intraseluler sehingga dapat mencegah terjadinya autolisis. Semakin banyak cairan intraseluler terikat dengan trehalosa maka interaksi hidrofobik intramolekuler akan semakin meningkat, sehingga kerusakan membran dan protein dapat dicegah (Leslie et al., 1995). Selain trehalosa, adanya zat terlarut betaine juga dapat membuat $C$. sakazakii resisten terhadap kondisi kering (Feeney et al., 2014). Menurut penelitian Riedel dan Lehner (2007) C. sakazaki dapat bertahan dalam keadaan kering karena adanya akumulasi protein yang berperan struktural dan protektif. Protein tersebut adalah protein heat shock (Hsp), protein cold shock (Cspc), protein perlindungan dan perbaikan (Dps), protein pengikatan DNA (Hns) seperti histon, dan protein protektif yang melawan oksigen radikal, superoksida dismutase, dan alkil hidroperoksida reduktase.

\section{Perubahan total bakteri pada jagung pipilan selama penyimpanan}

Total bakteri pada jagung pipilan mengalami penurunan selama 12 minggu penyimpanan pada ketiga $\mathrm{RH}$ (Gambar 5). Pada jagung pipilan dengan kadar air awal 12\%, total bakteri setelah penyimpanan pada $\mathrm{RH} 50,70,90 \%$ berturut-turut sebesar $2,3 \pm 0,15 ; 2,3 \pm 0,25$ dan 2,2 $\pm 0,14 \mathrm{Log} C F U / g$ dari

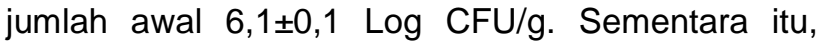
pada jagung pipilan dengan kadar air awal 16\%, total bakteri setelah penyimpanan pada $\mathrm{RH} 50,70$, $90 \%$ berturut-turut sebesar $2,8 \pm 0,06 ; 2,7 \pm 0,02$; dan 2,6 $\pm 0,08$ Log CFU/g dari jumlah awal 6,3 $\pm 0,05$ Log CFU/g. Total bakteri pada jagung pipilan setelah penyimpanan tersebut tidak berbeda signifikan meskipun kadar air awal dan $\mathrm{RH}$ yang berbeda.
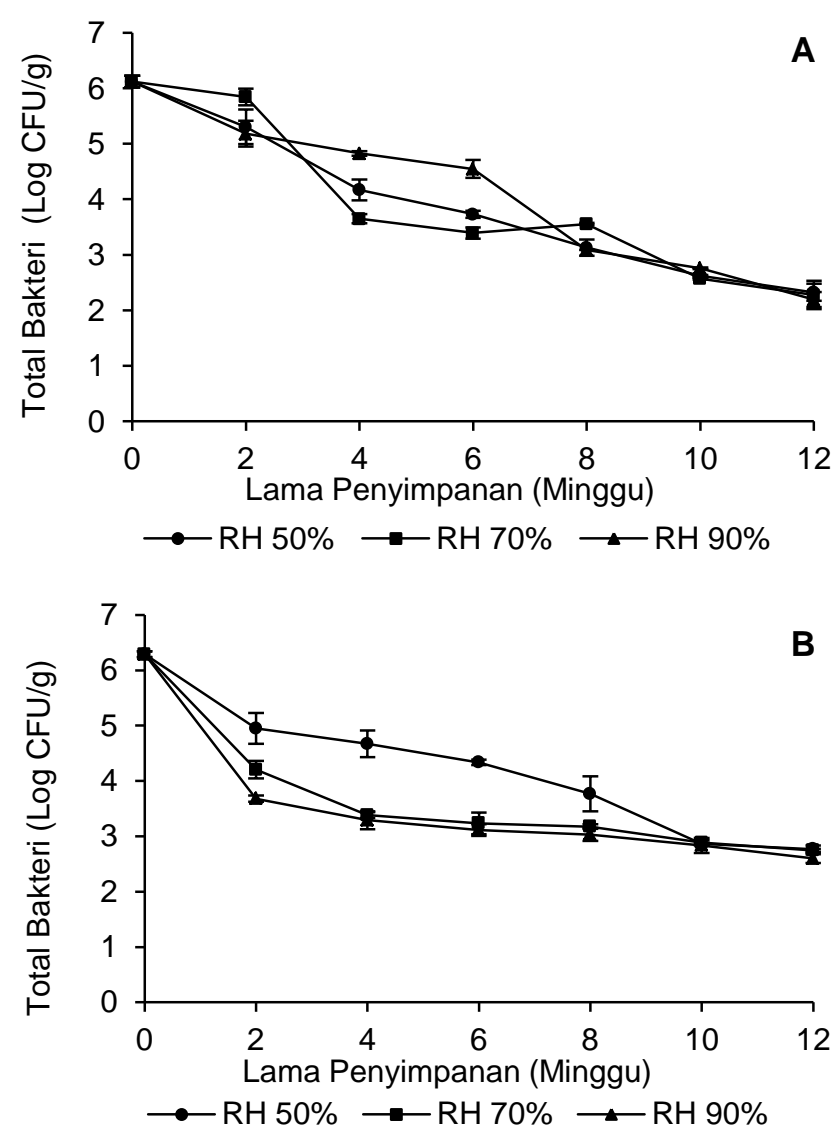

Gambar 5. Perubahan total bakteri pada jagung pipilan dengan kadar air awal $12 \%(A)$ dan $16 \%(B)$

Total bakteri di jagung pipilan berkadar air awal $12 \%$ turun lebih banyak daripada jagung pipilan berkadar air awal 16\% selama 12 minggu penyimpanan. Penurunan total bakteri di jagung pipilan berkadar air awal 12\% sebesar 3,8; 3,8; 3,9 Log CFU/g berturut-turut pada $\mathrm{RH} 50,70$, dan $90 \%$, sedangkan pada jagung pipilan berkadar air awal 16\% sebesar 3,5; 3,6; 3,7 Log CFU/g berturut-turut pada $\mathrm{RH} 50,70$, dan $90 \%$. Penurunan total bakteri pada $\mathrm{RH} 50$ dan $70 \%$ dapat disebabkan oleh penurunan nilai $a_{w}$ jagung pipilan selama penyimpanan dimana $a_{w}$ tersebut tidak sesuai untuk pertumbuhan bakteri. Nilai $\mathrm{a}_{\mathrm{w}}$ jagung pipilan berkadar air 12 dan $16 \%$ selama penyimpanan sebesar $0,43-$ 0,46 pada $\mathrm{RH} 50 \%$ dan 0,66-0,69 pada $\mathrm{RH} 70 \%$. Penelitian Leong et al. (2012) menemukan bakteri asam laktat (Lactobacillus plantarum, Leuconostoc 
citreum) muncul di awal penyimpanan dan bakteri Enterobacteriaceae dominan selama penyimpanan jagung. Akan tetapi, pertumbuhan bakteri asam laktat dan Enterobacteriaceae dipengaruhi oleh nilai $\mathrm{a}_{\mathrm{w}}$-nya, dimana bakteri asam laktat dan Enterobacteriaceae tidak dapat tumbuh berturut-turut pada $a_{w}$ di bawah 0,90 dan 0,95. Ketika bakteri terpapar pada lingkungan ber- $a_{w}$ rendah, jumlah air bebas pada jagung pipilan tersebut tidak cukup untuk mempertahankan viabilitas selnya sehingga sel mengalami dehidrasi dan tidak mampu untuk tumbuh atau bahkan mengalami kematian (Sperber dan Doyle, 2009). Sementara itu, penurunan total bakteri pada $\mathrm{RH} 90 \%$ dapat disebabkan oleh meningkatnya jumlah kapang dan khamir akibat meningkatnya $a_{w}$ jagung pipilan pada $\mathrm{RH} 90 \%$. Peningkatan jumlah kapang dan khamir tersebut menyebabkan interaksi antagonis dengan bakteri dalam bersaing mendapatkan nutrisi dari substrat jagung pipilan (Mille-Lindblom et al., 2006).

\section{Perubahan jumlah kapang dan khamir pada jagung pipilan selama penyimpanan}

Jumlah kapang dan khamir pada jagung pipilan berkadar air $12 \%$ setelah penyimpanan 12 minggu pada $\mathrm{RH} 50,70$, dan $90 \%$ berturut-turut adalah $3 \pm 0,01 ; 3 \pm 0,03$ dan $7,2 \pm 0,01$ Log CFU/g dari jumlah

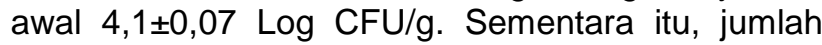
kapang dan khamir pada jagung pipilan berkadar air awal $16 \%$ setelah penyimpanan 12 minggu di $\mathrm{RH}$ 50, 70, dan $90 \%$ berturut-turut sebesar $3,5 \pm 0,14$; $4,2 \pm 0,11$ dan 7,4 $\pm 0,01 \mathrm{Log}$ CFU/g dari jumlah awal 4,1 $\pm 0,04 \mathrm{Log}$ CFU/g. Selama penyimpanan 12 minggu, jumlah kapang dan khamir pada jagung pipilan berkadar air awal $12 \%$ yang disimpan pada $\mathrm{RH} 50$ dan $\mathrm{RH} 70 \%$ mengalami penurunan sebesar 1,1 Log CFU/g, sedangkan pada $\mathrm{RH} 90 \%$ mengalami peningkatan sebesar 3,1 Log CFU/g, dan jumlah kapang dan khamir pada jagung pipilan berkadar air awal 16\% yang disimpan pada $\mathrm{RH} 50 \%$ mengalami penurunan sebesar $0,6 \mathrm{Log}$ CFU/g, sedangkan pada $\mathrm{RH} 70$ dan $\mathrm{RH} 90 \%$ mengalami peningkatan berturut-turut sebesar 0,1 dan 3,3 Log CFU/g (Gambar 6). Jumlah kapang dan khamir pada jagung pipilan setelah penyimpanan tersebut dipengaruhi oleh $\mathrm{RH}$ penyimpanan. Menurut Kusumaningrum et al. (2010), kelembaban relatif merupakan faktor yang mempengaruhi pertumbuhan kapang A. flavus pada jagung pipilan di daerah Bojonegoro selama penyimpanan.

Jumlah kapang dan khamir setelah penyimpanan pada jagung pipilan baik berkadar air awal 12 maupun $16 \%$ yang disimpan di $\mathrm{RH} 90 \%$ lebih besar daripada $\mathrm{RH} 50$ dan $70 \%$. Selain disebabkan oleh $\mathrm{RH}$ penyimpanan yang lebih tinggi, pertumbuhan kapang dan khamir pada $\mathrm{RH} 90 \%$ tersebut berkaitan dengan peningkatan $a_{w}$-nya, yaitu 0,83-0,87, yang merupakan $a_{w}$ yang sesuai untuk pertumbuhan kapang dan khamir. $a_{w}$ minimal untuk pertumbuhan kapang dan khamir pembusuk berturut-turut adalah 0,84 dan 0,90 (Sperber dan Doyle, 2009). Menurut Marin et al. (1998), kapang Aspergillus spp. pada media ekstrak jagung dapat bergerminasi pada $a_{w}$ 0,85-0,88, dimana Aspergillus niger mampu bergerminasi pada $\mathrm{a}_{\mathrm{w}} 0,8$, sedangkan Aspergillus flavus pada 0,85 . A. awamori yang diisolasi dari jagung pipilan memiliki $a_{w}$ minimal pertumbuhan 0,85 pada suhu $30^{\circ} \mathrm{C}$ (Astoreca et al., 2007).
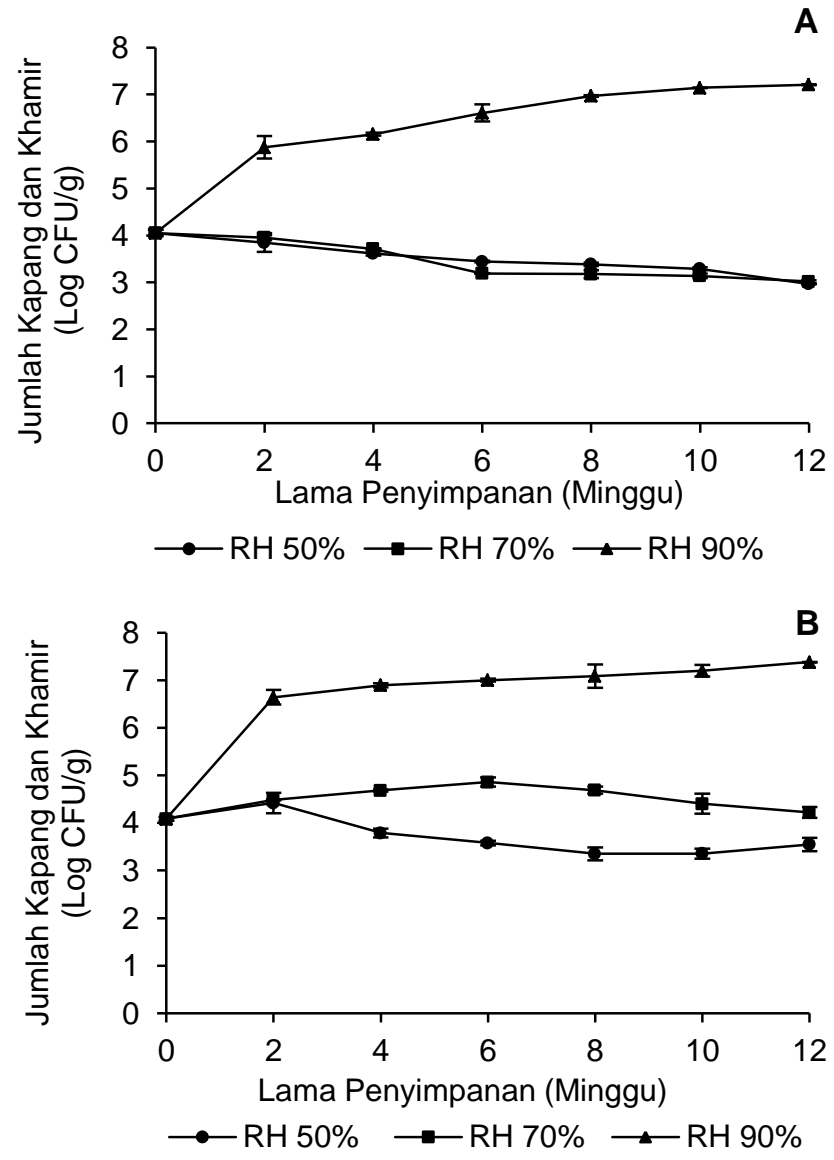

Gambar 6. Perubahan jumlah kapang dan khamir pada jagung pipilan dengan kadar air awal $12 \%$ (A) dan $16 \%(B)$

Selain karena $a_{w}$ jagung pipilan, pertumbuhan kapang dan khamir pada $\mathrm{RH} 90 \%$ juga disebabkan oleh peningkatan kadar airnya. Kadar air jagung pipil berkadar air awal 12 dan 16\% yang disimpan di $\mathrm{RH}$ $90 \%$ setelah penyimpanan sebesar $16-16,9$ sedangkan di $\mathrm{RH} 70 \%$ sebesar 12,3-13,4, dan di $\mathrm{RH} 50 \%$ sebesar 9,4-10,1. Menurut penelitian Reed et al. (2007) jagung yang berkadar air lebih tinggi mengalami pertumbuhan kapang yang lebih banyak daripada jagung yang berkadar air lebih rendah. Jumlah kapang pada jagung yang berkadar air 18\% lebih tinggi dibandingkan dengan jagung berkadar air $14,8 \%$ setelah penyimpanan selama 2 minggu pada suhu $25^{\circ} \mathrm{C}$. 


\section{KESIMPULAN}

Sintasan C. sakazakii pGFPuv pada jagung pipilan lebih dipengaruhi oleh $\mathrm{RH}$ ruang penyimpanan dibandingkan dengan kadar air awal jagung pipilan. C. sakazakii pGFPuv lebih bertahan hidup pada $\mathrm{RH} 50 \%$ dibandingkan $\mathrm{RH} 70$ dan $90 \%$ selama 12 minggu penyimpanan. Ketahanan hidup C. sakazakii pGFPuv ini berkaitan dengan kemampuannya untuk bertahan hidup pada kondisi $\mathrm{a}_{\mathrm{w}}$ yang lebih rendah selama penyimpanan di $\mathrm{RH} 50 \%$ yaitu $a_{w}$ 0,43-0,46. C. sakazakii pGFPuv dapat bertahan hidup pada $\mathrm{RH} 50 \%$, terutama pada jagung pipilan berkadar air awal 16\%. Dengan demikian, sebaiknya penyimpanan jagung pipilan dilakukan dengan kadar air awal $12 \%$ (bb) pada $\mathrm{RH} 50 \%$, karena selain menurunkan jumlah kapang dan khamirnya sebesar 1,1 Log CFU/g dan total bakteri sebesar 3,8 Log $\mathrm{CFU} / \mathrm{g}$, juga dapat menurunkan jumlah $C$. sakazakii sebesar 5,4 Log CFU/g.

\section{DAFTAR PUSTAKA}

Aguayo E, Escalona VH, Artes F. 2006. Effect of cyclic exposure to ozone gas on physicochemical, sensorial and microbial quality of whole and sliced tomatoes. Postharvest Biol Tech 39: 169-177. DOI: 10.1016/j.postharvbio. 2005.11.005.

Astoreca A, Magnoli C, Ramirez ML, Combina M, Dalcero A. 2007. Water activity and temperature effects on growth of Aspergillus niger, $A$. awamori and $A$. carbonariusisolated from different substrates in Argentina. Int $\mathrm{J}$ Food Microbiol 119: 314-318. DOI: 10.1016/j.ij foodmicro. 2007.08.027.

[BAM] Bacteriological Analytical Manual. 2001. Chapter 3: Aerobic plate count. http://www. fda.gov/Food/FoodScienceResearch/Laborator yMethods/ucm063346.htm [04 November 2014].

Beuchat LR, Kim H, Gurtler JB, Lin LC, Ryu JH, Richards GM. 2009. Cronobacter sakazakii in foods and factors affecting its survival, growth, and inactivation. Int J Food Micobiol 136: 204213. DOI: 10.1016/j.ijfoodmicro.2009.02.029.

Bowen AB, Braden CR. 2006. Invasive Enterobacter sakazakii disease in infants. Emerg Infect Dis 12: 1185-1189. DOI: 10.3201/eid1208.051509.

Breeuwer P, Lardeau A, Peterz M, Joosten HM. 2003. Desiccation and heat tolerance of Enterobacter sakazakii. J Appl Microbiol 95: 967-973. DOI: 10.1046/j.1365-2672.2003.02067.x.

Dewanti-Hariyadi R, Larasati F, Nuraida L. 2012. Survival of Cronobacter sakazakii in skim milk during spra drying, storage, and reconstitution.
J Teknol Industri Pangan 23: 186-192. DOI: 10.6066/jtip.2012.23.2.186.

Estuningsih S, Kress C, Hassan AA, Akineden Ö, Schneider E, Usleber E. 2006. Enterobacteriaceae in dehydrated powdered infant formula manufactured in Indonesia and Malaysia. J Food Protect 69: 3013-3017.

[FAO-WHO] Food and Agriculture OrganizationWorld Health Organization. 2008. Enterobacter sakazakii (Cronobacter spp.) in powdered follow-up formula: meeting report. Microbiological Risk Assessment Series, No. 15, Roma, Itali. hlm 1-86. http://www.who.int/food safety/publications/micro/MRA_followup.pdf. [04 November 2014].

Feeney A, Johnston CD, Govender R, O'Mahony J, Coffe A, Sleator RD. 2014. Analysis of the role of the Cronobacter sakazakii ProP homologues in osmotolerance. Gut Pathogens 6: 15. DOI: 10.1186/1757-4749-6-15.

Friedamann M. 2007. Review. Enterobacter sakazakii in food and beverages (other than infant formula and milk powder). Int $\mathrm{J}$ Food Microbiol 116: 1-10. DOI: 10.1016/j.ijfoodmicro. 2006.12.018.

Gitapratiwi D, Dewanti-Hariyadi R, Hidayat SH. 2012. Genetic relatedness of Cronobacter spp. (Enterobacter sakazakii) isolated from dried food products in Indonesia. Int Food Res J 19: 1745-1749.

Greenspan L. 1977. Humidity fixed points of binary saturated aqueous solutions. J Res Nat Bureau Stand-a Physics Chem 81A: 89-96.

Gurtler JB, Beuchat LR. 2007. Survival of Enterobacter sakazakii in powdered infant formula as affected by composition, water activity, and temperature. J Food Protect 70: 1579-1586.

Healy B, Cooney S, O'Brien S, Iversen C, Whyte P, Nally J, Callanan JJ, Fanning S. 2010. Cronobacter (Enterobacter sakazakii): An oppurtunistic foodborne pathogen - a review. Foodborne Pathog Dis 7: 339-350. DOI: 10.10 89/fpd.2009.0379.

Iversen C, Forsythe S. 2003. Risk profile of Enterobacter sakazakii, an emergent pathogen associated with infant milk formula. Trends Food Sci Techn 14: 443-454. DOI: 10.1016/S 0924-2244(03)00155-9.

Jackson EE, Flores JP, Fernandez-Escartin E, Forsythe SJ. 2015. Reevaluation of a Suspected Cronobacter sakazakii Outbreak in Mexico. J Food Protect 78: 1191-1196. DOI: 10.4315/0362-028X.JFP-14-563. 
Kingsly ARP, Ileleji KE. 2009. Sorption isotherm of corn distillers dried grains with solubles (DDGS) and its prediction using chemical composition. Food Chem 116: 939-946. DOI: 10.1016/j.food chem.2009.03.050.

Kusumaningrum HD, Suliantari, Toha AD, Putra SH, Utami AS. 2010. Cemaran Aspergillus flavus dan aflatoksin pada rantai distribusi produk pangan berbasis jagung dan faktor yang mempengaruhinya. J Teknol Industri Pangan 21: 171-176.

Leong S-LL, Niba AT, Ny S, Olstorpe M. 2012. Microbial populations during maize storage in Cameroon. Afr J Biotechnol 11: 8692-8697. DOI: 10.5897/AJB12.108.

Leslie SB, Israeli E, Lighthart B, Crowe JH, Crowe LM. 1995. Trehalose and sucrose protect both membranes and proteins in intact bacteria during drying. Appl Environ Microbiol 61: 35923597.

Lin LC, Beuchat LR. 2007. Survival of Enterobacter sakazakii in infant cereals as affeceted by composition, water activity, and temperature. Food Microbiol 24: 767-777. DOI: 10.1016/j. fm.2007.02.001.

Marin S, Sanchis V, Saenz R, Ramos AJ, Vinas I, Magan N. 1998. Ecological determinants for germination and growth of some Aspergillus and Penicillium spp. from maize grain. J Appl Microbiol 84: 25-36. DOI: 10.1046/j.13652672.1997.00297.x.

Mille-Lindblom C, Fischer H, Tranvik LJ. 2006. Antagonism between bacteria and fungi: substrate competition and a possible tradeoff between fungal growth and tolerance towards bacteria. Oikos 113: 233-242. DOI: 10.1111/j. 2006.0030-1299.14337.x.

Nielsen SS. 2010. Food Analysis Laboratory Manual. Second Edition. 17-20. Springer, West Lafayette IN, USA.

Nurjanah S, Dewanti-Hariyadi R, Estuningsih S, Suhartono MT. 2014. Stability and Growth Characteristic GFPuv-Labeled Cronobacter sakazakii Isolated from Foods. Food Sci Biotechnol 23: 1491-1496. DOI: 10.1007/s1 0068-014-0204-3.
Nurjanah S, Suhartono MT, Dewanti-Hariyadi R, Estuningsih S. 2013. Aplikasi mutan berfluoresens untuk mempelajari ketahanan hidup kolonisasi dan penetrasi isolat Cronobacter sakazakii selama pengeringan jagung. J Teknol Industri Pangan 24: 184-193. DOI: 10.6066/ jtip.2013.24.2.184.

Osaili T, Forsythe S. 2009. Desiccation resistance and persistence of Cronobacter species in infant formula. Int J Food Microbiol International 136: 214-220. DOI: 10.1016/j.ijfoodmicro.2009. 08.006.

Passot S, Cenard S, Douanial, Tréléal C, Fonseca F. 2012. Critical water activity and amorphous state for optimal preservation of lyophilised lactic acid bacteria. Food Chem 132: 16991705. DOI: 10.1016/j.foodchem.2011.06.012.

Patist A, Zoerb H. 2005. Preservation mechanisms of trehalose in food and biosystems. Coll Surface B: Biointerface 40: 107-113. DOI: 10.1016/j.colsurfb.2004.05.003.

Reed C, Doyungan S, loerger B, Getchell A. 2007. Response of storage molds to different initial moisture contents of maize (corn) stored at $25^{\circ} \mathrm{C}$, and effect on respiration rate and nutrient composition. J Stored Prod Res 43: 443-458. DOI: 10.1016/j.jspr.2006.12.006.

Restaino L, Frampton EW, Lionberg WC, Becker RJ. 2006. A chromogenic plating medium for the isolation and identification of Enterobacter sakazakii from foods, food ingredients, and environmental sources. J Food Protect 69: 315-322.

Riedel K, Lehner A. 2007. Identification of proteins involved in osmotic stress response in Enterobacter sakazakii by proteomics. Proteomics 7: 1217-1231. DOI: 10.1002/pmic. 200600536.

Sperber WH, Doyle MP. 2009. Food Microbiology and Food Safety. Compendium of the Microbiological Spoilage of Foods and Beverages. 89,267. Springer Science Inc, New York.

Strelec I, Popovic R, Ivanisic I, Jurkovic V, Jurkovic Z, Ugarcic-Hardi Z, Sabo M. 2010. Influence of temperature and relative humidity on grain moisture, germination and vigour of three wheat cultivars during one year storage. Poljoprivreds 16: $20-24$. 